\title{
Reflecting on error treatment in speaking among EFL Moroccan learners
}

\author{
Sana Sakale, Doctorate in Education \\ Mohammed V University-Souissi, Faculty of sciences of education, Rabat, Morocco
}

\begin{abstract}
During speech production, intervening psychological, sociolinguistic and pedagogical factors interfere in the process and cause the EFL teaching/learning process of speaking to be a highly demanding undertaking for both teachers and learners. Previous research has investigated some of these factors and pointed out agents that may affect students' oral performance such as automaticity and feedback. Correspondingly and basing on empirical research, the present article reflects on teachers' feedback on errors during the speaking phase particularly. It advances evidence of how in addition to other factors previously identified like vocabulary deficiency ${ }^{l}$ and error anxiety, one important factor is a perceptible delay in error repair in teachers' feedback on the speaking skill among EFL Moroccan learners during the speaking phase particularly.

Key words: reflections on speech production, teachers' feedback, error-repair, learners and teachers perceptions.
\end{abstract}

\section{Introduction}

Relying on previous research, evidence has been brought forward as to the complexity of the speaking process if gauged basing on a pluri-disciplinary exploration. From a psychological viewpoint (Levelt, 1989, 1994; Vecera \& O'Reilly, 1998; Goolkasian, 2000), it is a process entailing simultaneously the functioning of many other speech processes while from a sociolinguistic perspective, it is a discursively constructed phenomenon dependent on the functions of the language it serves in a social group (Austin, 1961,1962; Searle, 1969, 1979; Cameron, 2001) and on cultural and conversational strategies (Mauranen, 2006; Markee, 2008; Mckay,2008) that tailor most interactional or transactional situations. Pedagogically speaking however, the classroom entity constitutes a plausible field for the treatment, implementation and interaction of several of these dimensions in addition to the teaching methodology that incorporates how or in what way to tackle this complicated skill (Brown \& Yule, 1983; McCarthy, 1998; Folse, 2006; Bygate, 1991, 1998, 2001, 2009).

Therefore, and for the importance it holds during the EFL teaching/learning process of this controversial skill, feedback is found to be one among other important factors that influence the process and cause its alteration (Lyster \& Ranta, 1997; Ayoun, 2001; Swain, 2000, 2008; Savignon, 2008 ). Accordingly, the focus of the present article will be on empirically demonstrating how this important factor shows highly determinant for the speaking skill in the Moroccan classes particularly. Henceforth, the article will attempt to provide answers to the following questions:

1. What are the characteristics of teachers' feedback in Moroccan EFL classes?

2. How do teachers attend to learners errors ${ }^{2}$ in Moroccan secondary classes?

3 . Is there any effect of teaching experience on error correction?

\section{Design}

\section{Method}

The present article adheres to a mixed design modus operandi, it is both a qualitative and a descriptive one. A descriptive study may be used to elaborate on a theory, affiliate problems to current practice, gauge current practice or associate what others in similar situations are doing with corresponding practices while a qualitative one is used to gain insight into people's attitudes, behaviors, concerns, and in this instance teaching styles and methods of instruction. It is agreed upon that it involves focus groups, in-depth interviews, content analysis, ethnography of communication (Seliger and Shohamy, 1989:116), as well as evaluation and analysis of any unstructured interviews or checklists.

\footnotetext{
${ }^{1}$ Reference to previous article: Sakale, S \& Seffar, S. 2012. The role of lexis in developing EFL learners speaking skill. Sino- US English Teaching, 9(9)

${ }^{2}$ For practical reasons, error and mistake have been used interchangeably to allude to a wrong speech act, wrong pronunciation or use of grammatical structure (verb tense for instance)attributable to bad judgment, or ignorance, or inattention
} 
Therefore, the study attempts to explore teachers' perceptions and the characteristics of their feedback, the way teachers attend to learners' errors, and whether there is any effect of teaching experience on error correction (independent variables) and the speaking skill as a dependant variable. It examines whether and to what extent modifications in the independent variables cause or are linked to any observed differences in the dependent variable.

\section{Population Vs Sample}

The term population in a research context refers to all the members or objects of any defined group which might be taken or about which information might be given. A research population refers to the entire group to which the research results might apply. On the other hand, the term sample refers to the members of that population selected to take part in the investigation since it is impossible to include the entire target population. The population sample included in the study will be described in detail below.

\section{EFL teachers}

Forty EFL English teachers have contributed to this investigation. The teachers' population has been subdivided into four different categories ranging from those who have less than ten years to those who have more than twenty years using a scale of ten years difference for each category.

Table (1): Teaching Experience

\begin{tabular}{|l|l|l|}
\hline Years of experience & Frequency & Percent \\
\hline less than ten years & 21 & 52,5 \\
\hline more than ten years & 7 & 17,5 \\
\hline more than fifteen years & 2 & 5,0 \\
\hline more than twenty years & 10 & 25,0 \\
\hline Total & 40 & 100,0 \\
\hline
\end{tabular}

Half of the teachers' population have an experience of at least ten years with a corresponding percentage of $47.5 \%$ including a significant proportion of teachers ( $25 \%$ ) who have a considerably long experience as EFL teachers (more than 20 years) while $52.5 \%$ have an experience of less than ten years.

\section{Results}

Table (2): Teachers' reactions to learners' mistakes

\begin{tabular}{|l|l|l|l|l|l|l|l|l|l|}
\hline $\begin{array}{l}\text { How do you treat } \\
\text { grammatical } \\
\text { mistakes in your } \\
\text { students' } \\
\text { speaking? }\end{array}$ & $\mathrm{A}$ & $\mathrm{U}$ & $\mathrm{S}$ & $\mathrm{R}$ & $\mathrm{N}$ & $\mathrm{M}$ & $\mathrm{T}$ & $\mathrm{q}^{*}$ & $\mathrm{p}^{*}$ \\
\hline $\begin{array}{l}1-\text { You correct } \\
\text { them as soon as } \\
\text { they arise }\end{array}$ & $1.5 \%$ & $77.5 \%$ & $7.5 \%$ & $25 \%$ & $35 \%$ & $12.5 \%$ & $100 \%$ & 108 & .000 \\
\hline
\end{tabular}

*p<.05; * $q=108$ [ $A=$ always; $U=$ usually; $S=$ sometimes; $R=$ rarely; $N=$ never; $M=$ missing; $T=$ total; $q=$ chi-squared value; $p=$ probability]

Table (2) describes teachers' reactions to learners' grammatical mistakes and how a good proportion of teachers is recorded not to correct them. Highly significant corresponding q level and $p$ value capture this tendency. Proportions related to never and rarely reach a percentage of (60\%) adding rarely (25\%) and never (35\%). A more detailed crosstab with teaching experience shows the effect of teaching experience on mistake correction.

Table (3): Crosstab on the effect of teaching experience on mistake correction

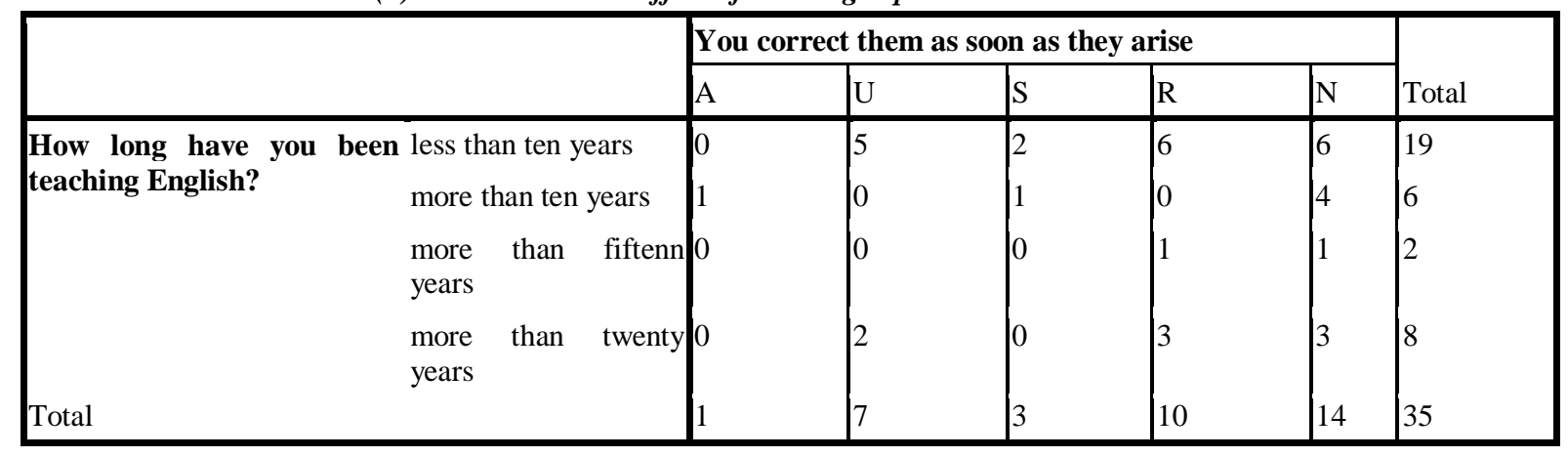


The above crosstab shows the general tendency of teachers' responses regarding error correction during speaking activities and the corresponding juxtaposition of these with teaching experience. The estimation shows a confirmation to what table 2 registers: a noticeable delay in error correction for all teaching experience categories.

These quantitative results are very indicative of the treatment of error correction, but more evidence will be brought with the qualitative results below:

Table (4): results of interviews with teachers on their feedback on learners' errors

\begin{tabular}{|l|l|l|}
\hline Teachers' Instructions and & $\begin{array}{l}\text { Treatment of grammatical } \\
\text { Fistakes in Ss speaking }\end{array}$ & $\begin{array}{l}\text { 1.Ignoring/ not correcting: 49\% } \\
\text { 2. Waiting \& pointing: 46\% } \\
\text { 3. Peer correction: 5\% } \\
\text { T=100\% }\end{array}$ \\
\hline
\end{tabular}

Qualitative findings as above table show capture a tendency of recurrence to same results as quantitative results above. Therefore, regarding error treatment for instance, qualitative findings show that nearly $50 \%$ ignore errors, $46 \%$ delay correction, and only $5 \%$ resort to peer correction and these include all teaching experience categories.

Two resulting arguments could be held: first that teaching experience has no effect on error correction, and second that a change in teachers' feedback (providing learners with a negative evidence) can result in improving learners speaking.

\section{Discussion}

Both qualitative and quantitative current findings retain that Moroccan teachers do not provide learners with a negative evidence when the learners commit mistakes/errors in form and do not negotiate the errors with them including different teaching experience categories investigated. Though meaning negotiation is done, form negotiation is either discarded or delayed. However, research done in this area shows that form negotiation serves the meaning too and helps learners establish the link between the form and the meaning of the utterances (Swain,1985, 2000, 2008; Lycaster,1998; Williams, 2008). More clearly, results related to teachers' feedback on errors in the present investigation reveal that teachers do not interrupt students to correct and/or negotiate the errors, and instead encourage them to talk even when they commit errors in message form (tables $2 \& 3$ above). The values registered, the chi-squared tests and the crosstabs capture the general tendency of teachers' responses regarding error correction and how a noticeable overlook or delay in error correction is witnessed during the speaking production phase particularly.

Accordingly, significant records regarding error treatment show that nearly $50 \%$ of teachers ignore errors, $46 \%$ delay correction, and only 5\% resort to peer correction (table 4 above). This is indicative of a deficiency at the level of negotiation and repair of the form of learners' utterances in Moroccan secondary EFL classes. Therefore, the chi- squared tests related to students' perceptions have diagnosed teachers' feedback as a highly significant variable during the teaching/learning process of the speaking skill, more particularly at the level of form negotiation and more precisely for repair including all teaching experience categories. Similar empirical results on this issue have been reached by Kouichi Ano (2002) when dealing with fluency and accuracy in the spoken English of Japanese high school learners. In addition, and quite interestingly, these findings have also shed light on the fact that repetitions and repairs can indeed be the cause of producing a larger number of words in class.

\section{Pedagogical implications}

The problematic query the current article raises concerns the extent to which a change in teachers' type of feedback such as providing learners with a corrective negative evidence when their answers are not accurate and encouraging them to do the repair can result in improving learners' speaking. In answer to this question, the findings of the present study provide evidence that it is indeed at the level of repair that Moroccan learners have the problem for all teaching experience categories. This leads to the tentative conclusion that repair can indeed be a factor in promoting accuracy while speaking in the target language which corroborates findings revealed by other studies such as those conducted by Ano $(1998,1998,2002)$. However, there remains the intertwined controversy concerning how many of the errors rectified by teachers will be recognized as such by learners and what techniques should be employed by teachers to enable learners to modify and ultimately repair their miscommunications.

Since in the present study results have shown that what is more problematic is rather 'form-negotiation', a suitable technique can be proposed which, as Williams explains, helps increase accuracy. This technique has been introduced by Muranoi (2000) and is described as a "pedagogical technique that interconnects input and output enhancement". Williams explains it as follows: 
.... in response to TL (teacher language) use, the teacher repeated learners' output, helping to confirm learners' hypotheses. In response to non-target like output, the teacher requested repetition, and if necessary, recast learner output. Muranoi found this technique effective in increasing accuracy... (p. 685)

The highly significant results related to pronunciation for instance urge for the necessity of repeating and recasting learners' output in Moroccan EFL secondary classes and negotiating the form of the utterances in an attempt to establish the link with meaning. Students' perceptions have revealed the need for this particular aspect of negotiation. This might serve as a technique to relate meaning to form and enhance learners' output. At the level of pronunciation, it should be noted that teachers' repetitions can be effective in stressing what to keep and follow and what to avoid or repair (Kenworthy, 1994; Florez, 1999; Hall, 1997).

A similar view is shared by Swain (2000) who holds that "modifications of learner output toward the target language by the intervention of an interlocutor/teacher" are effective as a method of providing concentrated feedback on form. Swain also calls them 'recasts' and qualifies them as 'a subset of feedback'. According to Williams (2008: 685), this is applicable either in experimental studies (Braidi, 2002; Mackey \& Philip,1998; Long,1998, Ortega, 1998), or in classroom studies (Ayoun, 2001; Doughty \& Varela, 1998). All such empirical studies evoked show the efficiency of recasts and interaction enhancement used by teachers who did not just reformulate the utterance but mainly used "emphatic and rising intonation in their repetition of the learner error" (Williams, 2008: 685), highlighting thus the learners' error before providing the accurate forms, which made their feedback less ambiguous for the learners. Applicability of such feedback on form can improve Moroccan learners' speaking.

\section{Conclusion}

Correspondingly, the values recorded for both the qualitative and quantitative results highlight the pivotal teachers' role in the whole process. Findings show that teachers from all teaching experience categories studied do not provide learners with negative evidence when learners commit errors in form and do not negotiate the errors with them. In parallel, a noticeable anxiety towards errors has been retained among learners and which may also be linked to the above signaled lack of form negotiation. Finally, some detectable interfering variables during the teaching/learning process of the speaking skill may be summed up as follows:

Table (5): some detectable interfering variables during the teaching/learning process of the speaking skill, potential areas of remedial interference and short-term and long-term effects on learners' speaking:

\begin{tabular}{|l|l|l|l|}
\hline $\begin{array}{l}\text { Empirically } \\
\text { detectable } \\
\text { interfering } \\
\text { variables in order } \\
\text { of importance }\end{array}$ & Areas of remedial interference & $\begin{array}{l}\text { Short-term effects on } \\
\text { learners'speaking }\end{array}$ & $\begin{array}{l}\text { Long term effects on } \\
\text { learners'speaking }\end{array}$ \\
\hline Teachers' role & $\begin{array}{l}\text { Teachers are invited to address } \\
\text { speaking on its own and avoid } \\
\text { any confusion while dealing } \\
\text { with it. Teachers are invited to } \\
\text { develop their instructional } \\
\text { methodologies while teaching } \\
\text { speaking }\end{array}$ & $\begin{array}{l}\text { Learners will not } \\
\text { withdraw in predictable } \\
\text { speaking situations since } \\
\text { they are comfortable and } \\
\text { familiar with them. }\end{array}$ & $\begin{array}{l}\text { Learners will identify what } \\
\text { they want to say in this } \\
\text { specific situation and } \\
\text { choose the best strategy to } \\
\text { say it. }\end{array}$ \\
\hline $\begin{array}{l}\text { Teachers' } \\
\text { feedback }\end{array}$ & $\begin{array}{l}\text { Teachers are invited to push } \\
\text { learners up towards speech } \\
\text { production and encourage them } \\
\text { in different ways }\end{array}$ & $\begin{array}{l}\text { Learners will be more } \\
\text { motivated to engage in } \\
\text { speaking }\end{array}$ & $\begin{array}{l}\text { Learners in later stages can } \\
\text { be more confident and } \\
\text { autonomous }\end{array}$ \\
\hline $\begin{array}{l}\text { Form negotiation/ } \\
\text { accuracy }\end{array}$ & $\begin{array}{l}\text { Negative evidence of the non } \\
\text { accuracy should be made clear } \\
\text { to the learners and negotiation } \\
\text { of errors should be made }\end{array}$ & $\begin{array}{l}\text { Learners can start to } \\
\text { establish the link between } \\
\text { the form of an utterance } \\
\text { and its meaning }\end{array}$ & $\begin{array}{l}\text { Learners can develop } \\
\text { awareness and recognition } \\
\text { of the form and meaning } \\
\text { and acquire the linguistic } \\
\text { competence needed to link } \\
\text { them }\end{array}$ \\
\hline Error- Repair & $\begin{array}{l}\text { Recasting errors and prompting } \\
\text { learners to bring modifications } \\
\text { in their speaking }\end{array}$ & $\begin{array}{l}\text { Modifications on learners' } \\
\text { speaking can start to take } \\
\text { place }\end{array}$ & $\begin{array}{l}\text { Less repetitions and shorter } \\
\text { pauses in learners' } \\
\text { speaking will be witnessed } \\
\text { both fluency and accuracy) }\end{array}$ \\
\hline
\end{tabular}




\section{Bibliography}

[1]. Ano, K. (1998). 'A Study of the Output Hypothesis: Cognitive Processes of Speaking a Foreign Language'. Journal of Japan Korea Association of Applied Linguistics, 2: 175-204

[2]. Ano, K. (1998). 'A Study of Cognitive Processes of Listening and Speaking in a Foreign Language'. The Bulletin of the Graduate School of Education of Waseda University, $6: 29-43$

[3]. Ano, K. (2002). 'The Relation between Fluency and Accuracy in the Spoken English of High School Learners'. Step Bulletin,14: $39-49$

[4]. Ayoun,D. (2001). ' The role of positive and negative feedback in the second language acquisition of the passé composé and imparfait’. Modern Language Journal, $85: 226-243$

[5]. Austin, J.L. (1962). How to do things with words. Massachussetts: Harvard University Press.

[6]. Austin,J.L. (1961). Philosophical papers. London: Oxford University Press.

[7]. Ayoun,D. (2001). 'The role of positive and negative feedback in the second language acquisition of the passé composé and imparfait'. Modern Language Journal, $85: 226-243$.

[8]. Braidi,S. (2002). Reexamining the role of recasts in native-speaker nonnative-speaker interactions. Language Learning, 52: 1-42.

[9]. Brown,G.\&Yule.G. (1983). Teaching the spoken language. Cambridge: Cambridge University Press

[10]. Bygate, M.(1998). 'Theoretical perspectives on speaking'. Annual Review of Applied Linguistics, 18: 20-42.

[11]. Bygate, M. (1991). Speaking. Hong Kong: Oxford University Press

[12]. Bygate, Martin (2009) 'Teaching and testing speaking'. In Blackwell. W (ed), The Handbook of Language Teaching, Chichester: Blackwell Handbooks in Linguistics: 412-440.

[13]. Bygate, M. (2001). 'Speaking'. In R. Carter \& D. Nunan (eds), The Cambridge Guide to Teaching English to Speakers of Other Language, Cambridge: Cambridge University Press. Chap. 2: 14-20.

[14]. Cameron, D. (2001). Working with spoken discourse. London: SAGE Publications Ltd.

[15]. Doughty,C.,\& Varela,E. (1998). 'Communicative focus on form'. In C. Doughty \& J. Williams (eds), Focus on form in classroom second acquisition, Cambridge : Cambridge University Press : 114-138.

[16]. Florez,M.C.(1999). 'Improving adult English language learners'speaking skills'. National Center for ESL Literacy Education, 5:16-20

[17]. Folse, K.S. (2006). The art of teaching speaking. Michigan: The University of Michigan Press.

[18]. Goolkasian, P. (2000). 'Pictures, words, and sounds: From which format are we best able to Reason?' The Journal of General Psychology, 127: 439-459.

[19]. Hall,S.(1997). 'Integrating pronunciation for fluency in presentation skills'. ERIC Digest ED 408 856. Retrieved September 15,2009 from ERIC database.

[20]. Kenworthy, J. (1994). Teaching English pronunciation. London : Longman.

[21]. Levelt, W. (1989). Speaking : from intention to articulation. Cambridge, Massa: MIT Press.

[22]. Levelt, W. J. M. (1994). 'The skill of speaking'. In P. Bertelson, P. Eelen, \& G. d'Ydewalle (eds), International perspectives on psychological science, Hove: Erlbaum: 89-103.

[23]. Long, M., \& Robinson,P.(1998). 'Theory, research and practice'. In C. Doughty \& J. Williams (eds), Focus on form in classroom second acquisition, Cambridge : Cambridge University Press : 15-41.

[24]. Lyster, R. (1998). Recasts, repetition, and ambiguity in L2 classroom discourse. Studies in Second Language Acquisition, 20: 5180.

[25]. Lyster, R \& Ranta, L. (1997). Corrective feedback and learner uptake: negotiation of form in communicative classrooms. Studies in Second Language Acquisition, 21: 557- 587.

[26]. Mackey,A.,\& Philip,J. (1998). Recasts, interaction, and interlanguage development: Are responces red herrings? Modern Language Journal, 82: 338- 356 .

[27]. Markee,N. (2008). 'Conversation analysis for second language acquisition'. In Hinkel Eli (ed), Handbook of research in second language teaching and learning, New York: Routledge: 355-371.

[28]. McCarthy, M. (1998). Spoken Language and Applied Linguistics. Cambridge: Cambridge University Press.

[29]. Mckay, S.L. (2008). 'Sociolinguistics and second language learning'. In Hinkel Eli (ed), Handbook of research in second language teaching and learning, New York: Routledge: 281-299.

[30]. Mauranen,A. (2006). 'Spoken discourse, academics and global English: a corpus perspective'. In Rebecca Hughes (ed), Spoken English, TESOL and applied linguistics: challenges for theory and practice, New York: Palgrave Macmillan: 143-158

[31]. Muranoi,H. (2000). 'Focus on form through interaction enhancement: integrating formal instruction into a communicative task in EFL classrooms'. Language Learning, 50: 617-673.

[32]. Ortega,L. (1999). 'Planning and focus on form in L2 oral performance'. Studies in second language acquisition, 21: 109-145

[33]. Searle, J. (1979). Expression and meaning: Studies in the theory of speech acts. Cambridge: Cambridge University.

[34]. Searle, J. (1969). Speech acts: An essay in the philosophy of language. Cambridge, England: Cambridge University

[35]. Searle, J. R., Ferenc Kiefer, and Manfred Bierwisch. (1980). Speech act theory and pragmatics. Dordrecht: D. Reidel.

[36]. Seliger, H.W \& Shohamy, E (1989). Second Language Research Methods. New York: Oxford University Press.

[37]. Savignon, S.J. (2008). 'Communicative language teaching: strategies and goals'. In Hinkel Eli (ed), Handbook of research in second language teaching and learning, New York :Routledge: $635-651$.

[38]. Swain,M . (1985). 'Communicative competence: some roles of comprehensible input and comprehensible output in its development'. In S.M. Gass \& C.G. Madden (eds), Input in second language acquisition, Rowley, MA: Newbury House: 235-254.

[39]. Swain,M. (2000). 'The output hypothesis and beyond: mediating acquisition through collaborative dialogue'. In Lantolf J.P (ed), Sociocultural theory and second language learning, New York: Oxford University Press: 97-114.

[40]. Swain, M. (2008). 'The output hypothesis: theory and research'. In Hinkel Eli (ed), handbook of research in second language teaching and learning, New York: Routledge: 471-483.

[41]. Vecera, S.P, \& O'Reilly, R (1998). 'Figure-ground organization and object recognition processes: an interactive account'. Journal of experimental psychology. Human Perception and performance, 24(2): 441-462.

[42]. Williams, J. (2008). 'Form-focused instruction'. In Hinkel Eli (ed), handbook of research in second language teaching and learning, New York: Routledge: 671-691. 